${ }^{\circledR}$ Entomologica Fennica. 20 September 1996

\title{
Incurvariidae and Prodoxidae (Lepidoptera) from Siberia and the Russian Far East, with descriptions of two new species
}

\author{
Mikhail V. Kozlov
}

Kozlov, M.V. 1996: Incurvariidae and Prodoxidae (Lepidoptera) from Siberia and the Russian Far East, with descriptions of two new species - Entomol. Fennica 7:55-62.

The Incurvariidae and Prodoxidae of eastern Russia total 19 species in eight genera. Phylloporia bistrigella (Haworth), now reported from Yukon, is tentatively included in the list, although it has not yet been discovered in the Eastern Palaearctic. Four species previously known only from Europe, Incurvaria vetulella (Zetterstedt), I. circulella (Zetterstedt), Lampronia luzella (Hübner), and L. provectella (Heyden) are reported from Siberia; Incurvaria kivatshella Kutenkova is synonymized with I. vetulella. Lampronia sakhalinella $\mathrm{sp} . \mathrm{n}$. is described from Sakhalin. L. altaica Zagulajev is reported from North Korea; the female postabdomen and genitalia of this species are described and figured. The genus Greya Busck, previously known only from North America, is reported from the Palaearctic, with G. variabilis Davis \& Pellmyr and $G$. kononenkoi sp. n. recorded from the Chukchi Peninsula, and G. marginimaculata (Issiki) comb. $\mathrm{n}$. originally described from Japan is expected from the Russian Far East. Among the nine species not known from Europe, one species is reported from Altai only; two show a Beringian distribution; six species are associated with the southern areas of the Far East and Japan, and one is distributed from the Irkutsk region to Sakhalin and Primorye.

Mikhail V. Kozlov, Laboratory of Ecological Zoology, University of Turku, FIN-20500 Turku, Finland

Received 23 February 1994, accepted 2 November 1995

\section{Introduction}

Data on the incurvarioid moths of Eastern Palaearctic is still scanty. Kozlov (1987) listed nine species of Incurvariidae and Prodoxidae (family-level taxa sensu Nielsen \& Davis 1985). Kuprijanov (1992a, b) added some distribution records of Procacitas orientella and discussed the taxonomic position of Allo- clemensia minima. Since no males of A. minima have been discovered yet, the generic affinities of this species remain unclear. The status of Incurvaria insignis Christoph, 1881, described from Vladivostok from a single female, has also not been clarified yet.

The incurvarioid fauna of the neighbouring countries has also been poorly investigated. No

"Report no. 20 from the joint Finnish-Russian entomological expeditions to Siberia (cooperative project no. 20 between the Academy of Finland and the Russian Academy of Sciences). 
species have been reported from China; only three species were included in the check-list of the Japanese fauna (Moriuti 1982) and a single species, Paraclemensia incerta, was found in Southern Korea (Park 1983). Therefore, any additional records from the Eastern Palaearctic can contribute a great deal to the better understanding of the species ranges.

Materials investigated have been mostly collected by the participants of the Finnish-Russian expeditions to Siberia (for the description of localities, see Mikkola 1988) and Chukchi Peninsula; specimens collected by K. Mikkola in Yukon, Canada, are also mentioned since the locality sampled had not been investigated earlier. Although some records from Southern Primorye and Sakhalin (based on specimens collected by the author) were reported earlier in Russian (Kozlov 1987), they are briefly mentioned below to make them available to the international scientific community.

Male genitalia are illustrated as described by Kozlov (1993). Abbreviations of museums and institutions: USNM = National Museum of Natural History, Smithsonian Institution, Washington, D.C., U.S.A.; ZIN = Zoological Institute, St. Peterburg, Russia; ZMUC = Zoological Museum, University of Copenhagen, Denmark. Specimens for which the depository is not indicated are kept in the Zoological Museum, University of Helsinki, Finland (ZMH).

\section{List of species}

\section{Incurvariidae}

\section{Phylloporia bistrigella (Haworth, 1828)}

Canada: $10^{\prime}$, Yukon Territory, $65^{\circ} 07^{\prime} \mathrm{N}, 138^{\circ} 16^{\prime} \mathrm{W}$, Ogilvie Mnts, Dempster Hwy km 155, 1650 m, snow field, 7.7.1985, Mikkola. There is no doubt that this species, widely distributed in both Europe and North America, will be discovered in Siberia.

\section{Incurvaria oehlmanniella (Hübner, 1796)}

Russia: 10', Irkutskaja obl., 50 km E Sljudjanka, river HaraMurin, taiga, Malaise trap, 10-30.7.1984, Mikkola \& Viitasaari. This transpalearctic species has been previously reported from Southern Primorye, Gornotajezhnoe near Ussurijsk and Kamtschatka, Kozyrevsk (Kozlov 1987).
Incurvaria vetulella (Zetterstedt, 1839)

= Incurvaria kivatshella Kutenkova, 1987, syn. n.

Russia: 107, Polar Ural, 14.7.1977, Sedykh; 11, SW Altai, 15 km S Katanda, Bert-Kum, 2 000-2 500 m, 10 14.7.1983, Mikkola, Hippa \& Jalava; 30'o', SW Altai, 7 km N Katanda, 2 200-2 500 m, 20-21.7.1983, Mikkola, Hippa \& Jalava; $2 \sigma^{\top} \sigma^{\top}$, Irkutskaja obl., Khamar-Daban, Meteorol. st., $1450 \mathrm{~m}, 14-15.7 .1984$, Mikkola \& Viitasaari. Canada: $10^{\prime}$, Yukon Territory, $65^{\circ} 07^{\prime} \mathrm{N}, 138^{\circ} 16^{\prime} \mathrm{W}$, Ogilvie Mts, Dempster Hwy km 155, 1050 m, 6.7.1985, Mikkola; 10’, same locality, $1650 \mathrm{~m}$, snow field, 7.7.1985, Mikkola.

Specimens collected in Siberia filled the gap in the distribution of this species previously known only from Europe (Laasonen et al. 1981) and North America (Davis 1983). The species is variable both in external traits and in male genital characteristics (Huemer 1993).

Investigation of the type specimen of Incurvaria kivatshella Kutenkova deposited in ZIN, showed that it is a junior synonym of $I$. vetulella. Absence of the thorn-like part at the apex of aedeagus in the sole known specimen of $I$. kivatshella does not contradict my conclusion; specimens without this process (might be lacking due to damage) have been discovered among the extensive samples of $I$. vetulella from Kevo Biological Station, Finnish Lapland.

\section{Incurvaria circulella (Zetterstedt, 1839)}

Russia: 10', Irkutskaja obl., Khamar-Daban, Meteorol. st., $1450 \mathrm{~m}$, taiga, 14-15.7.1984, ad luc., Mikkola \& Viitasaari; 1, same region, Oz. Serdce, 16.7.1984, 1500 m, Mikkola \& Viitasaari; 10', same region, Pik Tsherskogo, 1800 m, 1618.7.1984, ad luc., Mikkola \& Viitasaari. The first record from the Eastem Palaearctic; previously the species has been reported only from the northern montane areas of Europe (Laasonen et al. 1981).

Vespina nielseni Kozlov, 1987

Described from Southern Primorye; no additional records.

Paraclemensia incerta (Christoph, 1882)

Reported from Southern Primorye (Kozlov 1987), Japan (Moriuti 1982) and Southern Korea (Park 1983); no additional records.

Subclemensia taigae Kozlov, 1987

Described from Southern Primorye; no additional records. 


\section{Procacitas orientella (Kozlov, 1987)}

Russia: 10̛, Irkutskaja obl., 5 km E Sljudjanka, 6-8.7.1984, Mikkola \& Viitasaari. This species was described from Sakhalin and was later reported from the Irkutsk region, Primorye, and North Korea by Kuprijanov (1992b). Kuprijanov erected a monotypic genus Procatitas for this species, which was originally placed in the genus Alloclemensia Nielsen.

\section{Alloclemensia minima Kozlov, 1987}

Described from Southern Primorye and later reported from Sakhalin by Kuprijanov (1992a) who transferred this species to the genus Phylloporia Heinemann. However, the external appearance of the species is very different from $P$. bistrigella; therefore I prefer not to change the taxonomic position of $A$. minima until the male is discovered.

\section{Prodoxidae}

\section{Lampronia capitella (Clerk, 1759)}

Russia: 10', Novosibirsk, Akademgorodok, 10-20.6.1983, Mikkola, Hippa \& Jalava; 1, Magadan obl., Kolyma r., Sinegorje, Dam of Kolyma, scree slope, 4.7.1990, Kullberg, Kuussaari \& Nieminen. Although the species has been mentioned from the Far East (Gerasimov 1952), no specimens confirming these records are known (Kozlov 1987). On the other hand, the species has been reported from North America as well (Davis 1983).

\section{Lampronia luzella (Hübner, 1817)}

Russia: $20^{7} \sigma^{7}, \mathrm{SW}$ Altai, Kuragan valley, $15 \mathrm{~km}$ S Katanda, $1200 \mathrm{~m}$, taiga, 23-25.7.1983, Mikkola, Hippa \& Jalava. The easternmost record.

\section{Lampronia splendidella (Heinemann, 1870)}

Russia: $50^{7} 0^{7}$, SW Altai, 15 km S Katanda, Bert-Kum, 2000 $2500 \mathrm{~m}, 10-14.7 .1983$, Mikkola, Hippa \& Jalava. This is the easternmost record of the species, which had already been reported from Altai (Zagulajev 1978).

\section{Lampronia provectella (Heyden, 1865)}

Russia: 2థQ, SW Altai, $10 \mathrm{~km}$ W Katanda, Katun valley, 1200 m, taiga, 22-27.6.1983, Mikkola, Hippa \& Jalava.
$20^{7} \sigma^{7}, 1$, Irkutskaja obl., $5 \mathrm{~km}$ E Sljudjanka, ad luc., 67.7.1984, Mikkola \& Viitasaari. The easternmost record.

\section{Lampronia corticella (Linnaeus, 1758)}

Russia: 10', SW Altai, Kuragan valley, 15 km S Katanda, 1200 m, taiga, 23-25.7.1983, Mikkola, Hippa \& Jalava; $20^{7} 0^{7}$, same region, $10 \mathrm{~km}$ W Katanda, $1200 \mathrm{~m}$, taiga, 2227.6.1983, Mikkola, Hippa \& Jalava; 10', same locality, 1519.7.1983, Mikkola, Hippa \& Jalava. This species has been previously reported from Eastern Siberia and Sakhalin (Kozlov 1987), as well as from North America (Davis 1983).

\section{Lampronia flavimitrella (Hübner, 1817)}

Russia: 107, SW Altai, Kuragan valley, 15 km S Katanda, 1200 m, taiga, 23-25.7.1983, Mikkola, Hippa \& Jalava. 1o, Irkutskaja obl., $50 \mathrm{~km}$ E Sljudjanka, river Hara-Murin, taiga, ad luc., 12.7.1986, Mikkola \& Viitasaari. This transpalaearctic species has been previously reported from Sakhalin (Kozlov 1987).

\section{Lampronia redimitella Zeller, 1846}

A transpalaearctic species reported from Sakhalin, Kamtschatka and Korjakskii region, Eastern Siberia (Kozlov 1987); no additional records.

\section{Lampronia altaica Zagulajev, 1992}

Northern Korea: 1o, Ryanggang Prov., Paektusan Mts., 1400 m, Samjiyon, 13.7.1987, Jaros. Russia: 10', Central Yakutia, Aldan River, Kylasty, 8.8. 1993, Kaimuk. The first records outside the type locality (Altai Mts.), which indicate a relatively wide longitudinal range of this species. Since females (Fig. 1B) have not been previously investigated (Zagulajev 1992), I include the brief description of the female postabdomen and genitalia (Fig. $2 \mathrm{E}-\mathrm{G}$ ): stemum VIII distally widely rounded, length $1.3 \times$ width; tergum VIII slightly longer than sternum, lateral margins proximally invaginated; ductus bursae membranous, walls not thickened; corpus bursae with two stellate signa, each with 8-9 rays; length of rays equal to diameter of the body of signa.

\section{Lampronia sakhalinella sp. $\mathrm{n}$.}

Holotype $\sigma^{\prime}$, Russia, Sakhalin, $46^{\circ} 58^{\prime} \mathrm{N}, 142^{\circ} 45^{\prime} \mathrm{E}$, surr. of Yuzhno-Sakhalinsk, 3-12.7.1983, Kozlov (ZMH).

Diagnosis: Close to L. redimitella, from which it differs by larger size, absence of transverse fascia at the forewing base, and position of pecten. From $L$. quinquepunctata Nielsen 

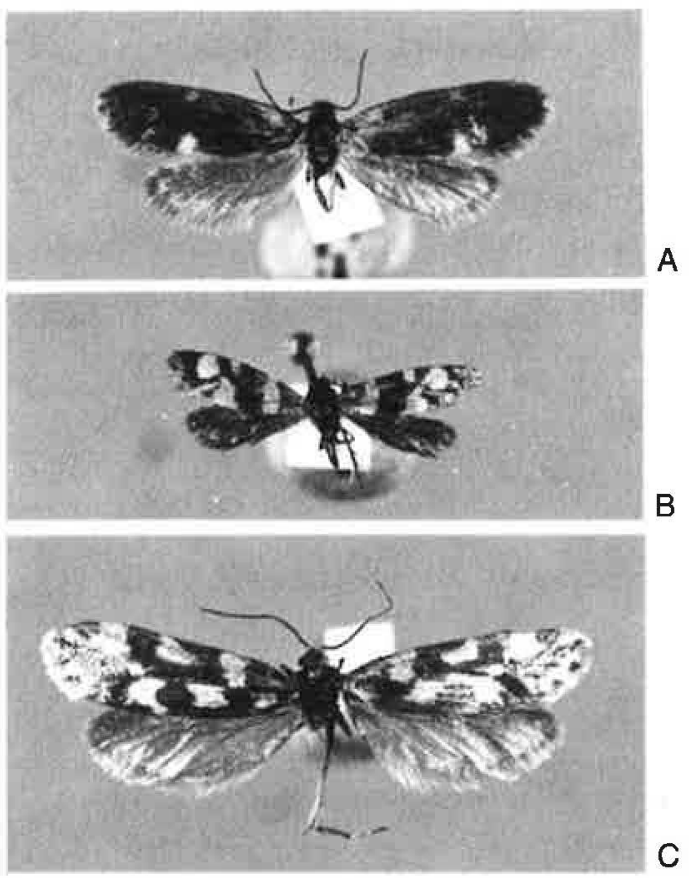

Fig. 1. Moth habitus. A: Lampronia sakhalinella sp. $\mathrm{n}$. (holotype, male); B: Lampronia altaica Zagulajev (female): C: Greya kononenkoisp.n. (holotype, male). - Scale: $1 \mathrm{~mm}$.

the species differs by the absence of basal spots on forewing and by a wider cucullus. 'I'he male genitalia are very similar to those of $L$. altaica Zagulajev, but differ by the absence of a comutus in the aedeagus and presence of a large posteriodorsal process on transtilla.

Description: Male (female unknown). Wing expanse $13 \mathrm{~mm}$. Head with appressed greyish fuscous scales. Interocular index 0.65 . Antenna $0.4 \times$ length of forewing, greyish-fuscous; flagellum with 19-20 segments. Maxillary palpi, haustellum, and labial palpi greyish fuscous. Tegulae and dorsum of thorax greyish fuscous; venter greyish. Forewing (Fig. 1A) pale greyish fuscous, with slight bronzy shine; pale luteous maculation consisting of small costal spot and larger $(0.25 \times$ width of forewing) triangular dorsal spot, both at $2 / 3$ of forewing length. Cilia greyish fuscous. Hindwing uniformly fuscous-grey, cilia of same colour. Abdomen pale brown to fuscous. Male genitalia (Fig. 2A-D): Vinculum twice as long as valva; in ventral projection not different from those of $L$. redimitella. Basal part of valva widely rounded, without spines at ventral margin. Length of cucullus about twice its maximum width; ventral margin basally with semi-round extension possessing pecten formed by $16-18$ spinose setae. Aedeagus slightly longer than vinculum, with local spinose sclerotization inside at about $2 / 3$ from the base. Juxta short, about $0.4 \times$ length of aedeagus; arrow-head length twice its width.
Etymology: named after Sakhalin Island, the type locality of the species.

\section{Greya variabilis Davis \& Pellmyr}

Russia: $10^{\prime}$, Chukchi Pns., $64^{\circ} 55^{\prime} \mathrm{N}, 172^{\circ} 30^{\prime} \mathrm{W}, 5 \mathrm{~km} \mathrm{E}$ Provideniya, 50-200 m, 7.7.1991, Mikkola; 107, 1\%, same region, $45 \mathrm{~km}$ N Provideniya, Pestsovaya river valley, 10.7.1991, Mikkola; 2070', same locality, 11.7.1991, Mikkola; 20̛ơ', 10, same locality, 15.7.1991, Mikkola; 10', same region, 55 km NNE Provideniya, Mt. Nirvenei, 270-500 m, 18.7.1991, Mikkola; 1o, same region, $35 \mathrm{~km}$ NE Provideniya, 25.7.1991, Mikkola. Canada: $20^{7} \sigma^{\prime}$, Yukon Territory, $65^{\circ} 07^{\prime} \mathrm{N}$, $138^{\circ} 16^{\prime} \mathrm{W}$, Ogilvie Mnts, Dempster Hwy km 155, $1050 \mathrm{~m}$, 4.7.1985, Mikkola; 3oo, same locality, $1000 \mathrm{~m}$, bog, 9.7.1985, Mikkola; $10^{7}$, same locality, 1300 m, 14.7.1985, Mikkola.

This species, recently described from North America, was expected to show Beringian distribution (Davis et al. 1992), which is now confirmed by the records from Chukchi Peninsula. However, the extent of the distribution in northem Siberia remains unclear.

Greya marginimaculata (Issiki, 1957) new combination

Japan: $10^{7}$ (lectotype, here designated), Honshu, Nagano, Tokusava, 24.7.1955, A. Mutuura (USNM); $10^{\top}$ (paralectotype, here designated), same locality, 22.7.1955, A. Mutuura (USNM); $30^{7} \sigma^{7}$ (paralectotypes, here designated), same data as in the previous paralectotype (ZMUC).

The lectotype has been labelled as such by E. S. Nielsen in 1979, but never designated through publication. This species, described as a member of the genus Lampronia Stephens from Honshu, Japan, can probably be found in eastern Russia as well. Within the genus Greya Busck, this species is most similar to $G$. variabilis and $G$. kononenkoi.

\section{Greya kononenkoi sp. n.}

Type material: Holotype $\sigma^{7}$, Russia, Chukchi Pns., $66^{\circ} 59^{\prime} \mathrm{N}$, $179^{\circ} 02^{\prime} \mathrm{W}$, Amguema, 26.7.1986, Kononenko (MZH). Paratype , Russia, Chukchi Pns., $64^{\circ} 55^{\prime} \mathrm{N}, 172^{\circ} 30^{\prime} \mathrm{W}, 5 \mathrm{~km}$ E Providenija, 7.7.1991, Mikkola (MZH).

Diagnosis: Closely related to G. marginimaculata, from which it differs by light spots on ventral forewing margin situated opposite gaps between light spots on the costal margin, by possessing a short vinculum almost equal to valvar length and by the anterolateral processes arising from the transtilla far away from each other, at the distance exceeding the width of uncus. The male genitalia are remarkably similar to Lampronia splendidella, which, however, belongs to another genus of Prodoxinae, and is very different in external appearance. 


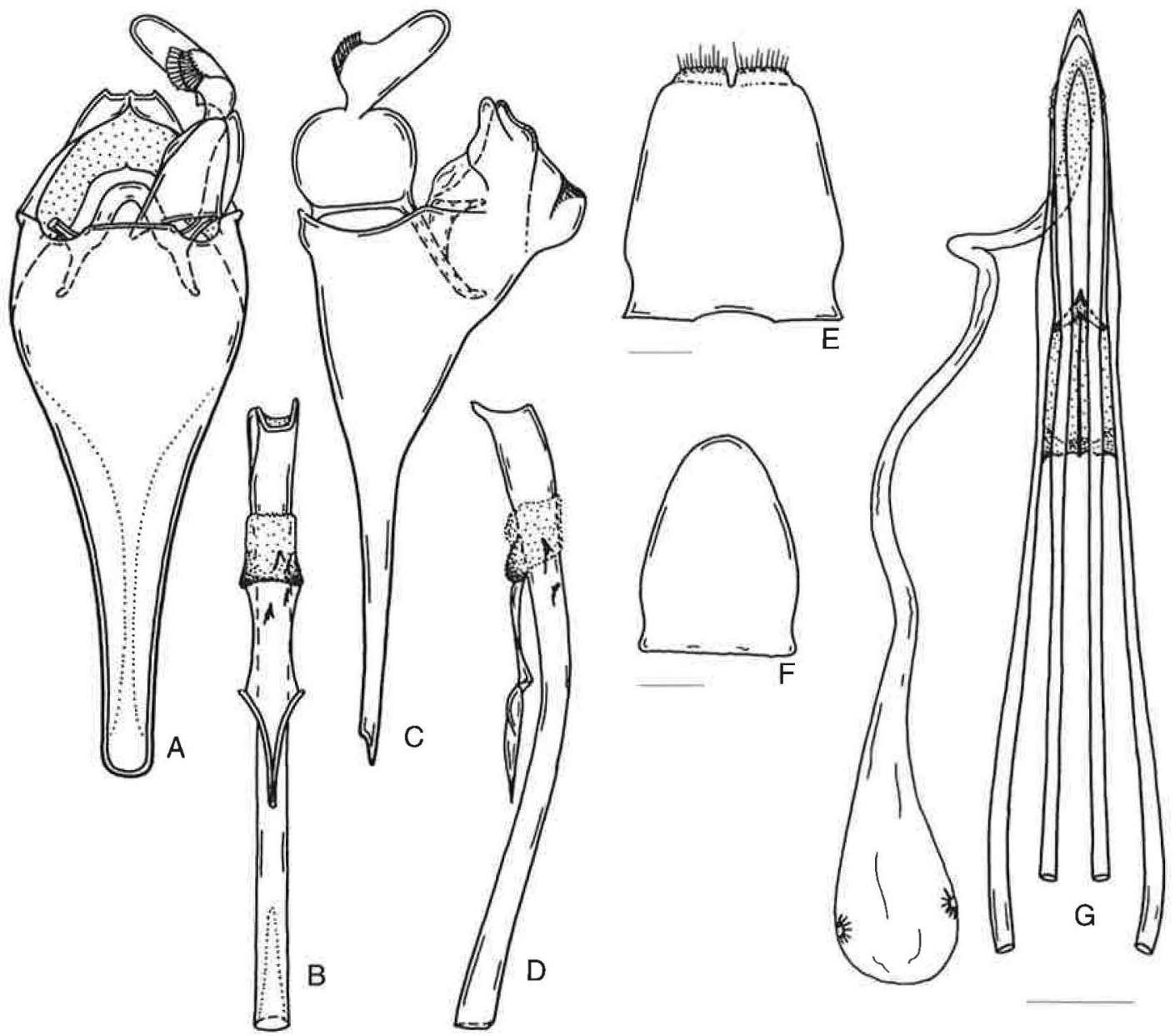

Fig. 2. Male genitalia of Lampronia sakhalinella sp. n. (holotype). A \& C: anellus and valvae; B \& D: aedeagus. (A \& B: ventral view; C \& D: lateral view). Female postabdomen and genitalia of Lampronia altaica Zagulajev. E: tergum VIII. F: sternum Vill. G: genitalia. — Scale: $0.25 \mathrm{~mm}$.

Description: Male. Wing expanse $15 \mathrm{~mm}$. Head with raised fuscous brown to pale grey scales. Interocular index about 0.7 . Antenna $0.4 \times$ length of forewing; scapus whitish grey, flagellum dark fuscous, with 28 segments, densely pubescent. Maxillary palpi, haustellum, and labial palpi fuscous. Tegulae and dorsum of thorax fuscous; venter greyish to fuscous. Forewing (Fig. 1C) brownish fuscous, with slight bronzy shine; white maculation consists of three large costal spots, three large dorsal spots and four minor spots at wing apex (one at costal, three at terminal margin). Cilia pale grey to white. Hindwing uniformly grey, cilia pale grey to white. Abdomen pale brown to fuscous. Male genitalia (Fig. 3AB): Uncus prominently bilobed. Length of vinculum approximately equal to that of valva. Valva broad, length $2 \times$ width; pollex very short, terminating in single, short spinose seta. Anterolateral processes arise from the lateral arms of transtilla, forming a U-shaped figure. Aedeagus with promi- nent, angulate sclerotization projecting at right angles from apex. Arrow-head of juxta apically rounded, length about 1.5 $x$ width.

Female. Wing expanse $14 \mathrm{~mm}$. Head white to pale fuscous, palpi pale grey, scapus white. Tegulae white, dorsum pale grey to fuscous. Otherwise similar to male. Female postabdomen (Fig. 3C-D): sternum VIII equal in length to tergum VIII, comprising about 0.6 of length of apophyses posteriors. Female genitalia (Fig. 3E): Ductus bursae membranous, with a group of minute, well-sclerotized teeth at about the middle of ductus; walls not thickened; corpus bursae without signa.

Habitat: The female was collected in low-shrub tundra (K. Mikkola, pers. comm.).

Etymology: Named after Dr. Vladimir Kononenko, the Russian lepidopterist, who collected the holotype.

Notes: The affinity of the species to the genus Greya, 


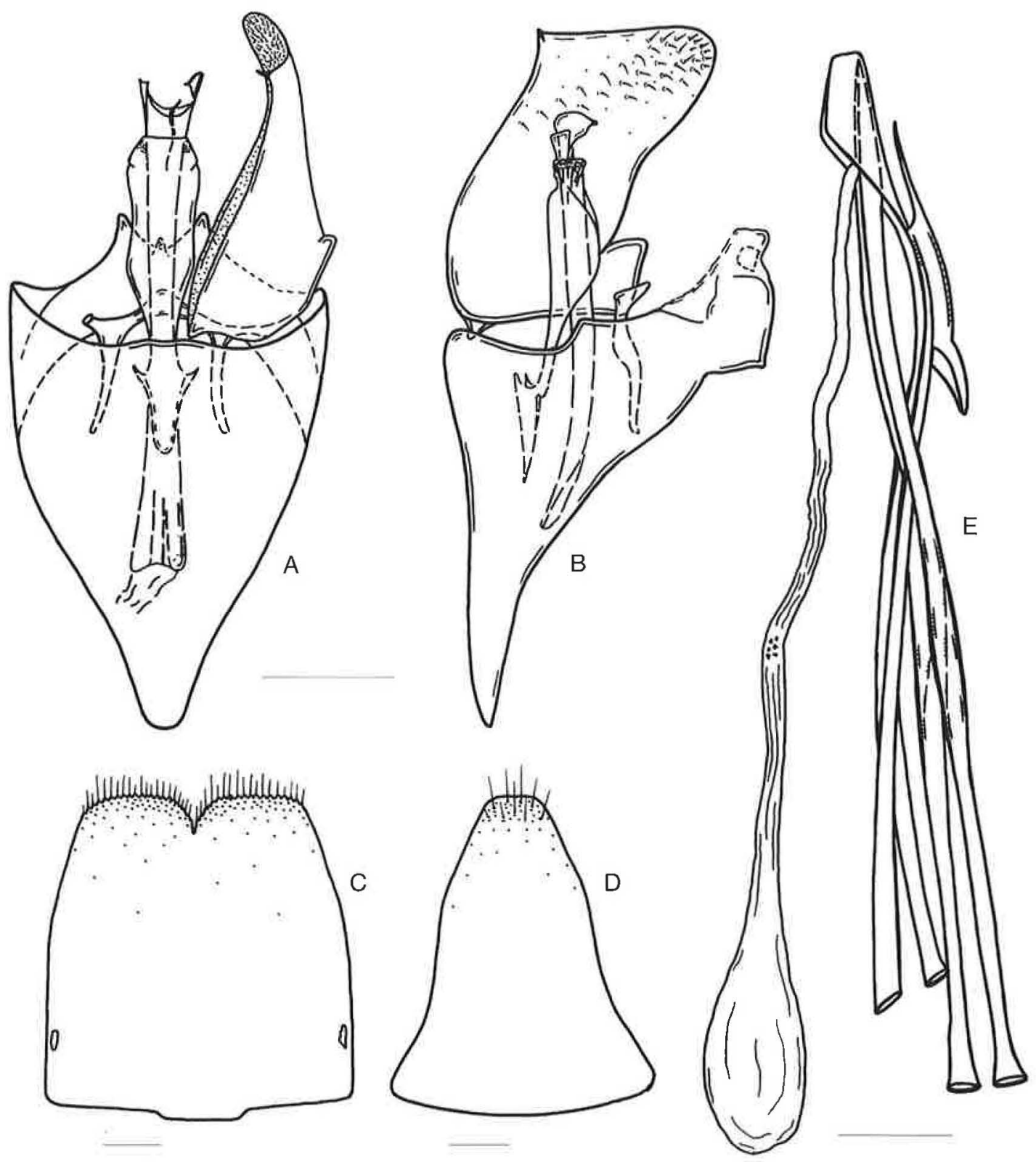

Fig. 3. Greya kononenkoi sp. n. A-B: male genitalia (holotype, ventral and lateral views, respectively), C-D: female postabdomen (tergum VIII and sternum VIII), E: female genitalia (paratype). — Scale: $0.25 \mathrm{~mm}$.

not Lampronia, is shown by external characters listed by Davis et al. (1992): the proboscis of $G$. kononenkoi is much longer than the maxillary palpi, while in Lampronia the proboscis does not exceed the length of the palpi.

The female was associated with the male on the basis of the wing pattern: in $G$. kononenkoi the inner margins of the large forewing white spots are perpendicular to the forewing margin, while in $G$. variabilis they extend along the medial line towards the forewing base. The female considered as $G$. kononenkoi has the tergum and sternum VIII of equal length, while females determined as $G$. variabilis have the length of tergum VIII about $1.3 \times$ lenght of stemum VIII. 


\section{Discussion}

Among the 20 species recorded from the Eastern Palaearctic, 10 species belong to the European fauna. Two of them, Lampronia splendidella and L. provectella, distributed in Central Europe, were discovered in the mountain regions of Altai and Khamar-Daban. The other eight species have a wider range; they are generally transpalaearctic or even Holarctic, and possibly both Incurvaria circulella and Lampronia luzella will be discovered further east than the most recent finds (Khamar-Daban and Altai, respectively).

While two genera of the group under study (Incurvaria and Lampronia) are common to the Eastern and Western Palaearctic and even extending into the Nearctic region, the genus Greya shows a Beringian distribution. Four other genera, each represented by a single species, as well as Alloclemensia minima, for which the generic placement is uncertain, are associated with southern regions of Siberia and Primorye.

Quite surprisingly, the fauna of Incurvariidae and Prodoxidae of Eastern Russia includes only one species common with Japan, Paraclemensia incerta. Whether this fact reflects the existence of a strict zoogeographic border between Southern Primorye and Japan or just poor knowledge of both faunas remains open to speculation. However, it is worth mentioning that at least six undescribed incurvarioid species are known from Japan (E. S. Nielsen, pers. comm.).

Acknowledgements. I gratefully acknowledge the willingness of K. Mikkola and J. Jalava to study the specimens kept in MZH, as well as the comments of K. Mikkola on the earlier draft of the manuscript. I thank V. S. Kononenko and J. Jaros for the donation of material, D. R. Davis for information concerning the North American fauna, N. P. Kristensen and E. S. Nielsen for permission to study specimens of undescribed Japanese species, and S. Koponen for access to specimens collected in Kevo, northern Finland. The study has been supported by the Academy of Finland and the University of Copenhagen.

\section{References}

Davis, D. R. 1983: Incurvarioidea, pp. 3-4. - In Hodges, R. W., Dominick, T., Davis, D. R., Ferguson, D. C., Franclemont, J. G., Munroe, E. G., Powell, J. A. (eds.):
Check list of the Lepidoptera of America North of Mexico. E. W. Classey Ltd., London. 284 pp.

Davis, D. R., Pellmyr, O. \& Thompson, J. N. 1992: Biology and systematics of Greya Busk and Tetragma, new genus (Lepidoptera: Prodoxidae). - Smiths. Contrib. Zool. 524:1-88.

Gerasimov, A. М. (Герасимов, А. М.) 1952: [Caterpillars]. Fauna of the U.S.S.R., Lepidoptera, 1 (2). 338 pp. (in Russian).

Huemer, P. 1993: Review of Incurvaria vetulella speciesgroup in the Alps (Lepidoptera: Incurvariidae). Entomol. Scand. 24:109-120.

Issiki, S. 1957. Incurvariidae, pp. 10-11. - In Esaki, T., Issiki, S., Inoue, H., Mutuura, A., Ogata, M., Okaagaki, H.: Icones Heterocerorum Japonicorum in coloribus naturalibis. Hoikusha, Osaka, 318 pp. (in Japanese).

Kozlov, M. V. (Козлов, М. В .) 1987: [Moths of subfamilies Incurvariinae and Prodoxinae (Lepidoptera, Adelidae) of Far East], pp. 14-24. - In Ler, P. A., Kirpichnikova, V. A. \& Kononenko, V. S. (eds.): [Lepidoptera of the Far East of U.S.S.R.]. Biological and Soil Institute, Vladivostok, 128 pp. (in Russian).

- 1993: New species of Cauchas Zeller (Lepidoptera: Adelidae) from the Altai and Tianshan Mountains. Nota Lepidopterologica 16:113-123.

Kuprijanov, A. V. 1992a: Towards a natural system of Incurvarioidea. Part 1: On the systematic position of Alloclemensia minima Kozlov, 1987 (Lepidoptera, Adelidae). - Atalanta 23:633-636.

— 1992b: Towards a natural system of Incurvarioidea. Part 2. Procacitas gen. nov, for Alloclemensia orientella Kozlov, 1987, with new data on the distribution (Lepidoptera, Incurvariidae s.str.). - Atalanta 23:637-642.

Kutenkova, N. N. (Кутенкова, Н. Н.) 1987: A new species of moths of the genus Incurvaria Hw. (Lepidoptera, Incurvariidae) from Karelia. — Entomol. Obozr. 66:627629 (in Russian).

Laasonen E., Jalava J. \& Nielsen, E. S. 1981: The identity of Incuvaria vetulella (Zetterstedt, 1839) and I. circulella (Zetterstedt, 1839), two distinct species (Lepidoptera: Incurvariidae). - Entomol. Scand. 12:57-64.

Mikkola, K. 1988: The subarctic and boreal components of the noctuid communities of the southern Siberian mountains, as indicators of postglacial movements of noctuid fauna (Lepidoptera, Noctuidae), pp. 95-111. - In Zlobin, V. V. (ed.): The connections between entornofauna of the North Europe and Siberia. Zoological Institute, Leningrad, $188 \mathrm{pp}$.

Moriuti, S. 1982: Incurvariidae, pp. 155-156. — In Inoue, H., Sugi, S., Kuroko, H., Moriuti, S., Kawabe, A. (eds.): Moths of Japan, 2. Tokyo, 392 pp.

Nielsen, E. S. \& Davis, D. R. 1985: The first Southern Hemisphere Prodoxid and phylogeny of the Incurvarioidea (Lepidoptera). — Syst. Entomol. 10:307-322.

Park, K. T. 1983: Microlepidoptera of Korea. - Insecta Koreana, Ser. 3. Seoul, 195 pp. 
Zagulajev, A. K. (Загуляев, А. К.) 1978: [Fam. Incurvariidae], pp. 75-92. - In Medvedev, G. S. (Memenes, Г. C .) (ed.): Key for determination of insects of the European part of the U.S.S.R.] 4 (1). Nauka, Leningrad, 711 pp. (in Russian).
- 1992: New and little known microlepidoptera (Lepidoptera: Incurvariidae, Tineidae, Psychidae, Alucitidae) of the fauna of the USSR. V. - Entomol. Obozr. 71:105-120 (in Russian). 